\title{
Can the Tudor Conquest of Ireland be usefully compared to the Nazi Genocide?
}

\author{
William Palmer \\ Department of History \\ Marshall University \\ 1 John Marshall Drive \\ Huntington, WV 25755, USA
}

A few decades ago, such a question would have seemed absurd. The Nazi Genocide and the path to it seemed unique. In the 1920s Adolf Hitler, an embittered veteran of World War I, tapped into a powerful undercurrent of anti-Semitism in Germany that could be traced back to the Middle Ages. Even though Germany was far from being Europe's most anti-Semitic nation, Germany's loss in World War I and the economic collapse that followed required a scapegoat and the Jews made a tempting target. They could be blamed for the Bolshevism that infected the home front and the German army in the last months of the war. Jewish industrialists could be blamed for betraying the German army by failing to keep it supplied and urging the high command to make peace. In the troubled economic times that followed the war, Jewish moneylenders could be charged with taking advantage of impoverished soldiers and workers by loaning them money at extortionate rates. In 1922 Hitler declared, "once I really am in power my first and foremost task will be the extermination of the Jews...I will have gallows built in rows...until the last Jew in Munich is exterminated."

Hitler also believed that Germany's destiny depended upon the acquisition of new land, and he envisioned the creation of a German empire in Eastern Europe modelled on the British Empire in India where the Slavic peoples of Eastern Europe would provide slave labor for their German masters. In 1941 Hitler declared, "what India was for England, the territories of Russia will be for us." But at some point before the invasion of the Soviet Union in the summer of 1941, Hitler decided instead that it was necessary to carry out the destruction of all European Jews and inferior peoples in order to create "living space" in Eastern Europe for German settlement. Finally, Hitler, having rescued Germany from economic disaster and restored national pride, had no problem finding Germans willing to kill Jews. As Hans Frank, the Nazi governor general in Poland, declared after his appointment, "What a pleasure to be finally able to tackle the Jewish race physically, the more that die, the better.",

More importantly, the scope and scale of the Nazi Genocide appeared to be unprecedented. While precise totals of Nazi killing will probably never be known, roughly six million Jews were murdered, along with approximately two million ethnic Poles, three million Soviet prisoners of war, and perhaps even more Soviet civilians. Half a million gypsies perished. The Nazis also deliberately executed Catholic priests and many from the Polish upper class as well as Soviet commissars. And there were other atrocities. In 1939 Hitler ordered the killing, usually by lethal injection, of Germans who were mentally handicapped. About 70,000 people were killed before public outcry forced an end this practice in August, 1941. There were also several hundred thousand Germans sterilized by Nazi officials between 1934 and 1943 for simplemindedness, alcoholism, chronic depression, schizophrenia, or other conditions that might dilute the master race. Nazi doctors performed barbaric experiments on concentration camp inmates. ${ }^{4}$

In the face of this massive slaughter and accompanying cruelties, the Tudor Conquest of Ireland appeared to be a minor episode. There was certainly anti-Irish sentiment among English deputies and officials. In 1571 Edward Tremayne wrote that the Irish "murder, commit whoredom, hold no wedlock, ravish, steal and commit all abomination without scruple or conscience." There was also a long list of violent episodes perpetrated by the English against the Irish. These episodes included the invasion of Ireland by the earl of Surrey in 1520, the massacres of "Silken Thomas" Fitzgerald and his five uncles following their surrender on terms after the Kildare Rebellion in 1534-5, of women and children by the earl of Essex at Rathlin Island in 1575, of the O'Mores in 1577 after they had been invited to parley at Mullaghmast, and of unarmed papal troops after their surrender at Smerwick in 1580. There was also a campaign of "scorched earth" during the Tyrone Rebellion, in which the English systematically laid waste to the lands of the earl of Tyrone with little regard for the people inhabiting them. ${ }^{6}$

But there was no Hitler, no speeches or writings to prove serve as a plan, no massive, state-sponsered apparatus and bureaucracy deliberately constructed to murder the Irish. And the amount of death and devastation in Ireland, while difficult to calculate, seemed to pale in comparison with the comprehensive slaughter of the Nazi Genocide. Thus, the Tudor Conquest of Ireland scarcely seemed comparable. 
That conquest appeared to be best understood in the context of a fairly common process in early modern Europe, by which emerging national states asserted their authority against various borderlands and peripheries. In this case, Irish lords in the twilight of their fading power, struggled heroically but futilely to resist that process. ${ }^{7}$ And there were other cautions. Irish lords themselves were responsible for much of the violence inflicted upon the Irish population, as violence was often a necessary device for the maintenance of their authority over lesser lords and tenants.

Moreover, the sixteenth century was a violent age across Europe in many respects, and the episodes that characterized the Tudor conquest, such as massacres of soldiers even after their surrender on terms and retribution against civilians, were replicated in almost all early modern state building and warfare. ${ }^{8}$ The Nazi Genocide, thus, appeared to be unique in both conception and scale, and, if compared at all, it was probably best understood against other large-scale genocides, such those perpetrated by the Turks against the Armenians, or by Stalin and Mao against their own peoples. ${ }^{9}$

Historical understanding, however, in both the Nazi Genocide and Tudor Conquest of Ireland has changed dramatically in recent years and both can now be seen in vastly different terms. And with changes in historical understanding, it may also now be possible to see, with important qualifications, the Tudor Conquest and the Nazi Genocide as comparable events. ${ }^{10}$ Admittedly, the two fields are among the more highly contested areas of historical study, stirring powerful emotions and peopled with tenacious scholars ready to engage in hand-to-hand combat to defend their points of view. But recent research has unveiled some new perspectives, from which a partial, provisional truth may emerge. If we turn first to the historiography of the Nazi Genocide, perhaps no field has changed more dramatically in recent years. First, it is now clear that the idea of Hitler as the all-powerful force directing the Nazi Genocide is misleading, although few would deny his critical role. But in recent work Hitler appears more as a "big picture" strategist, who was more likely to hint at what he wanted to happen rather than order it, and who tended to leave the details to his subordinates. ${ }^{11}$

Moreover, it once seemed clear to historians that Hitler's writings and speeches provided evidence that he planned to destroy European Jews well before he came to power. But, on the basis of recent scholarship, it is now appears that even by the time of the invasion of the Soviet Union in June, 1941, there was no plan, no agreement among Nazi officials about how the "Jewish Question" should be handled. In Germany Hitler's policies in the 1930s, such as the removal of Jews from universities and the civil service, the boycott of Jewish businesses, the Nuremburg Laws, and even Kristallnacht, were not about rounding up German Jews and killing them. Instead, they appear to be more about making the circumstances of life in Germany so miserable for German Jews that they would leave.

It is also clear that the conquest of Poland in 1939 forced Nazi officials to confront several unexpected difficulties. Unlike Austria and the Sudetenland, where the annexed peoples were largely ethnic Germans, that group was a minority in Poland, and Nazi officials did not anticipate the difficulties involved in dealing with the enormous populations of such groups, including Jews and ethnic Poles, that they regarded as inferior. The initial plan, approved by Hitler, was to round up Polish and German Jews, and about 30,000 gypsies, force them into cattle cars, and transport them to a strip of land between the Vistula and Bug Rivers in the eastern part of German-occupied Poland. This plan, however, was eventually scrapped in favor of a more ambitious scheme to settle ethnic Germans into the newly conquered territories. The new plan, developed under the guidance of Heinrich Himmler, now focused on the removal of Polish Jews along with ethnic Poles from the newly conquered territories to create space for the German settlers. Deportation of German Jews was placed on hold. ${ }^{12}$

But it soon became clear that the transportation and resettlement of such an enormous number of people was impossible given the resources available to the Nazi officials in charge. Ghettoization of Polish Jews in urban areas offered a partial solution to this problem, but officials in Poland implemented it without being entirely clear about its purpose. Some thought its purpose was to starve the ghettoized Jews to death or wait for disease to take its toll; others thought it was simply a device to keep them separate from the non-Jewish population until they could be deported elsewhere. Nazi officials also considered the possibility of deporting the Jews to Madagascar or some other distant territory. ${ }^{13}$

The invasion of the Soviet Union further complicated racial matters. In July,1940, after failing to defeat Great Britain, Hitler ordered his general staff to develop plans for such an invasion. And, in January, 1941 Himmler informed S.S. officials of an important change in policy. Instead of transforming the Slavic populations of Eastern Europe into a slave labor force, the plan was now to kill them, possibly as many as thirty million people, in order to create "living space" for German settlers. ${ }^{14}$ But even this directive posed problems. The invasion of the Soviet Union commenced in June, 1941, and was initially a dazzling success. Killing squads, called Einsatzgruppen, had been assigned to follow in the wake of invasion troops and kill survivors. But when the invasion dragged on, Nazi leaders realized that they could not feed adequately both the soldiers in the field and the civilians at home. Cognizant that the deprivation of food and fuel had weakened the German home front in the last months of World War I, they decided not to ask the German people for sacrifice. The approximately 3.5 million man invasion force would be expected to live off the land. ${ }^{15}$ This decision had several important consequences. 
It meant, for example, that the soldiers were ordered to be utterly ruthless toward the civilian population, at least some of whom actually welcomed the invasion, in order to seize their livestock, grains, or other foodstuffs. With several million men of their own to feed, the Wehrmacht could not afford to feed a civilian population. Nor could it afford to feed the approximately two million Soviet prisoners of war it took during the first several months of the invasion; they would have to be killed or starved to death. ${ }^{16}$ Mobile killing squads moving from town to town to kill Jews were also utilized in Poland.

But even in this operation Nazi officials had different ideas. At first they intended to kill only adult, Jewish males, but Himmler decided that failure to kill women and children would create "a nation of avengers," who, if allowed to live, might rise up at some later date and exact a fearful revenge on those responsible. ${ }^{17}$ German officials soon discovered other problems. The reserve troops who formed the ranks of the killing squads soon began to suffer psychological damage from having to murder hundreds of innocent people every day. ${ }^{18}$ In some cases the Nazis turned to partisans, or local persons, who, in their eagerness to please their new masters, might be willing to undertake the killing. Ultimately, the enormity of the task would require, following the Wannsea Conference, convened in early 1942, that they turn to gas chambers as the preferred means of killing Jews. It was, in the famous phrase of Ian Kershaw, more efficient and humane, that is, more efficient and humane for the executioners, not the victims. Thus, most historians of the Nazi Genocide, though not all, would agree that at least until the invasion of the Soviet Union, there was no agreement that all European Jews would have to be killed, much less on a plan about how to go about it.

Another issue that historians of the Nazi Genocide are in general agreement about is the importance of bureaucracy in the execution of Jewish policy. While earlier studies of the Nazi Genocide focused on Hitler and ideology, in the early 1960s, scholars like Raul Hilberg and Hannah Arendt, and, subsequently, Martin Broszat and Christopher Browning, began the study of the bureaucrats charged with carrying it out. ${ }^{19}$ Among other things, they discovered many officials in the Nazi hierarchy, like Himmler and Heydrich, were people whose advancement in society had been thwarted in the aftermath of World War I. When the Nazi seizure of power provided new opportunities for wealth and power, these men eagerly seized them. ${ }^{20}$ A major part of the Nazi Genocide included the confiscation of virtually every kind of Jewish asset, including property, bank accounts, valuable art, and, even cold weather clothing. Hans Frank, the Governor-General of Poland, filled two warehouses with contraband intended for himself and his family. So rapacious was Nazi looting that quarrels even broke out between high-ranking officials, including Frank and Herman Goring, about getting their fair share of it. ${ }^{21}$

The result was a mad scramble among different departments and individuals within the Nazi hierarchy and puppet governments to find ways to please Hitler or their German masters. The Nazi Genocide was caused largely by a toxic collision between leaders who believed that it was necessary to destroy the Jewish race, the exigencies of war, and ambitious bureaucrats who were eager to win favor from their superiors. Like the officials in the Nixon administration during the Watergate crisis, they did not require explicit orders; they had learned that those who proposed the harshest measures, proclaimed their anti-Semitism the most loudly, and appeared to be the most zealous in pursuing them would be the ones who would reap the greatest rewards. The Nazi Genocide was thus to a great extent, an improvised process, dependent upon the interplay of contingent, unforeseen circumstances, and corruption as well as individual and bureaucratic initiatives. ${ }^{22}$

The circumstances just described could also be applied to the Tudor Conquest of Ireland. As there was no plan followed by the Nazis to exterminate Jews, there was no English plan for the conquest of Ireland, indeed, no agreement about what policies should even be pursued in Ireland. English policies toward Ireland during the sixteenth-century were varied, often driven by the need to save money, and usually reactive. As early as 1520, the English made a brief attempt to take Ireland by force in an expedition led by the earl of Surrey. In the late 1530s in the aftermath of the Kildare Rebellion, the English abandoned the traditional policy of allowing Ireland to be governed by local Irish lords, and attempted to govern it instead through English-born deputies and a paid military force. In the 1540s, Sir Anthony St. Leger became lord deputy in Ireland, and he believed that money could be saved and disagreeable Irish customs and practices eradicated by education and exposure to more civilized English practice. St. Leger advocated a policy of "surrender and regrant," by which Irish lords would surrender their lands to the crown, and, then receive them back as fiefs. In this way, St. Leger hoped to create an Irish lordship loyal to the crown with common interests. ${ }^{23}$

St. Leger's plan, based at least partly on the humanist doctrines of Thomas Starkey, took an optimistic view of England's chances of controlling Ireland. It could, in his view, be accomplished with persuasion rather than force. But by 1547, the English had returned to aggressive policies. Sir Edward Bellingham constructed a network of garrisons along the frontier of the Pale. The garrison strategy was also pursued by Thomas Radcliffe, the third earl of Essex and the English deputy in Ireland from 1556 to 1563. 
Sussex also conceived the idea for the Laios-Offaly Plantation, whereby land would be set aside for Irish settlement, but its communities would be modelled upon English law, society, and methods of cultivation. ${ }^{24}$

One of the devices utilized by Sussex was the imposition of martial law. Originally intended as a device to subdue those engaged in active rebellion, by the mid-1500s martial law had been expanded to serve as a preemptive measure to crush dissent before it became rebellion. At the beginning of Elizabeth's reign, martial law was usually directed against the poorest elements of society. But, by the 1570s, martial law was being employed against virtually every segment of the Irish population.

In 1573 Edward Fitton, the chief commissioner in Connaught, was authorized to employ martial law "without any limitation." More seriously, martial law permitted the officers enforcing it to execute people without charge, even simply for "suspicion of wrongdoing," and to receive a share of the wealth of those they killed. The English captain Thomas Lee thought that martial law was a necessary tool for those who governed "remote and savage places," until those they governed embraced civil society. ${ }^{25}$ Regardless of how they tried to polish it up, in the end, the English position was summarized by Edmund Spenser when he declared that "all is the conqueror's, as Tully to Brutus saith."26

Martial law was also employed by Sussex's successor in Ireland, Sir Henry Sidney, appointed in 1565, and whose policies generally expanded upon those begun by Bellingham and Sussex. Sidney believed that reform schemes for Ireland that simply tinkered with laws or policies would fail. And, where most previous English policy initiatives for Ireland had usually been designed to maintain English authority in the Pale, the area around Dublin, Sidney proposed to bring all Ireland under control through colonization and the extension of English authority into other parts of the island. By employing a force of English-born commanders and soldiers, he intended to take land and power from Irish lords and redistribute it to more loyal Englishmen and lesser Irish lords. ${ }^{27}$

Sidney initially targeted northeast Ulster and southwest Munster, areas long viewed by the English as antithetical to their interests. But seizing land held legally by others posed some ethical problems to the English mind, and English thinkers and officials developed an ideology of colonization to justify their actions. English policymakers convinced themselves that the Irish were not a civil people and that neither of the ruling elites in Ireland, the Gaelic Irish or "Old English" of the Pale could be trusted to govern. Therefore, "New English," or English-born officials, must assume responsibility. ${ }^{28}$

Although the Queen had instructed Sidney that the native Irish population should be "well-used," the English imposed their will in Ireland ruthlessly. In 1569 in the face of native resistance, Sir Humphrey Gilbert was appointed military governor of Munster and given almost unrestricted power of martial law. Gilbert waged a total war against "man, women, and child," so that "the name of an Inglysh man was made more terrible now that to the sight of a hundryth were before." These actions were underscored by an attitude of ruthlessness on the part of the perpetrators. Thomas Churchyard claimed that the slaughter of even non-combatants was necessary, "so that the killing of them by the sword was the way to kill all menn of warre by famine." 29

Similarly violent actions were undertaken in 1574 during the Rathlin Island massacre, when an English force led by Walter Devereaux, the first earl of Essex, slaughtered the entire population of the island. Like the actions of Humphrey Gilbert, Essex's behavior testified to an attitude of utter ruthlessness on the part of the English. One of Essex's officers, Edward Barkley, described how Essex's men drove the victims from their homes and into the surrounding woods where they would either starve or freeze to death in the oncoming winter. Barkley concluded "how godly a dede it is to overthrewe so wicked a race the world may judge: for my part I think there cannot be a greater sacrifice to God." ${ }^{30}$

One of the factors that convinced the English to pursue a more aggressive policy in Ireland was the threat posed by the Counter Reformation. The Reformation in England, in addition to introducing dangerous divisions at home, deprived England of traditional allies, such as Spain, and made them the target of Catholic powers in Europe. It also created enormous risks and problems when English officials attempted to extend the Reformation to Ireland. The population of Ireland was thought to remain loyal to the Catholic Church, and the attempt to extend reformed religion to Ireland helped provoke the Kildare Rebellion in 1534. Even after the rebellion had been subdued, an English observer commented that "the danger from the [Kildares] is greater than ever...the alleged cause of this treason is that the king is a heretic and obeys not the Bishop of Rome."31

With its extensive coastline, combined with inability of the English to extend their control much beyond the Pale, Ireland presented a tempting opportunity for the forces of the Counter Reformation, and it posed enormous logistical problems for those English officials charged with its defense. From Ireland an invasion of England could be launched and, in the event of a rebellion begun with foreign assistance, the English would have to divert significant amounts of men, money, and resources to quash it. ${ }^{32}$ 
By the early 1560s, as Sir Henry Sidney was devising his plans for Ireland, England was surrounded by Catholic powers, and Ireland was regularly viewed as a base from which a Catholic invasion of England might be attempted. The Jesuit David Wolfe once instructed Philip II of Spain that "he who will win England, let him in Ireland begin." 33 In 1560Sussex wrote Elizabeth that a foreign invasion of Ireland,which he considered imminent, posed multiple dangers. First, it could be easily accomplished by "a foreign power aided by a civil faction." Second, such an invasion would not only succeed in Ireland, but it would also "ensure ruin into England." ${ }^{34}$ In 1561 Christopher Hatton described Ireland, "as the postern gate through which those bent on the destruction of the country night enter.",

William Cecil feared that English papists were "gathering money and would be ready to move when some foreign force be ready to assail England or Ireland." ${ }^{36}$ In the same year Nicholas Throckmorton wrote Cecil that the French have "laid their baits in England, Scotland, and Ireland.",37

It is tempting to dismiss English concerns about foreign intervention in Ireland as paranoia. But, expressions of anxiety came steadily after the 1540s from a wide spectrum of observers, including the soberest of statesmen like Cecil, zealots like Walsingham, and English agents at foreign courts, as well as English officials in Ireland. Even if foreign threats did not materialize, perceptions of reality could be as compelling as reality itself. As Jennifer Loach has written, Tudor monarchs were "haunted by the notion of a Catholic crusade, blessed and abetted by the pope, and their pursuit of allies, as well as their treatment of Scotland and Ireland, was governed by that fear." 38 Fears of a Catholic conspiracy, as Malcolm Thorpe has suggested, provided an elan vital, which often drove policy decisions. ${ }^{39}$

In 1579 fears of Catholic conspiracy in Ireland became reality during the events surrounding the rebellion of Gerald Fitzgerald, the fourteenth earl of Desmond. As "New English" servitors in Ireland continued to extend their authority, "Old English" lords, such as Desmond, became increasingly threatened by theEnglish incursion into their authority. In 1579 Gerald's cousin, James Fitzmaurice Fitzgerald, returned from Europe in command of a papal force of sevenhundred men, and a charge to proclaim the papal bull, Regnans in Excelsis, in which the Pope invited rebellion against Elizabeth. The bull excommunicated the Queen, called upon Catholics to remove her and absolved Englishmen from any allegiance to her. Desmond initially tried to remain neutral, but soon cast his lot with the rebels. ${ }^{40}$

The two greatest English fears for Ireland had now materialized. The first fear was that continental Catholic powers could foment a rebellion in Ireland, and the second was that the Old English lords in Ireland could not be trusted to crush it. English officials quickly embarked on a harsh campaigns of destruction of life and property in areas under Desmond's control. In the end Desmond was captured and executed along with a small band of his followers.

But, before Desmond's death, a second rebellion erupted, this time in the Pale itself, and led by James Eustace, Viscount Baltinglass. Supported by a papal force of 600 men, there was some hope among its leaders that the rebellion might unite the disparate elements within Ireland. But, again, swift action on the part of English officials prevented a merger and forced the rebel forces to barricade themselves in the fort of Dun an Oir. The English commander, Arthur, Lord Grey de Wilton, ordered a bombardment of the fort. With a few days the commander of the papal forces offered to surrender. Grey accepted the surrender without conditions, but, after the captives gave up their weapons, he ordered his men to massacre all $600 .^{41}$

Many at Elizabeth's court, and even the Queen herself, were horrified, and Grey was recalled. But the events surrounding the 1579-80 rebellions testify to the increasing anxiety felt by English officials regarding Ireland. The Desmond and Baltinglass rebellions confirmed long-standing English fears that Ireland could serve as a base for Catholic powers eager to encourage rebellion and discord in Ireland. The possibility of seizing greater control in Ireland had clearly been under consideration by the English for some time. But the Desmond and Baltinglass rebellions, and the dangerous international situation forced an increasing number of English officials to conclude that yet sterner measures and expanded control, were needed in Ireland.

Thus, like the Nazis toward Jews and Poles, there was never an agreed upon policy among English officials for dealing with Ireland. At different times, and never in accordance with a consistent pattern, English officials tried invasion, conciliation, martial law, and colonization. Policy decisions usually depended upon immediate circumstances, often subject to sudden change, availability of funds or lack thereof, international threats, and the ambitions of various deputies, most of whom were aware that retaining their positions depended upon their ability to keep Ireland under control.

One of the clear forces driving the conquest of Ireland was the opportunities its conquest provided for ambitious English deputies, officials, and military men. Like the Nazi bureaucrats, English deputies and their subordinates usuallywent to Ireland hoping to acquire wealth, power, property,or favor at court. The so-called "West Country gentlemen," referring to those who came to Ireland from Devonshire, and included Arthur Champernoun, Peter Carew, Humphrey Gilbert, Richard Grenville, and Edward Tremayne, are the most obvious examples. ${ }^{42}$ Much can also be learned about English attitudes from the behavior of English military captains in Ireland. 
These men were often the younger sons of English landowners, which meant they had little chance to inherit land in England. Like many Nazi officials, they usually felt aggrieved and frustrated by the times or nursed personal grievances. Many of them, for example, had also served England against the Scots and French, and believed that they had been decidedly undercompensated for their service by the crown, leaving them embittered and desperate. In their view Ireland offered the opportunity for wealth and power, and perhaps their last one. As Sir Henry Wallop remarked about them, that even "had they nothing when they came hither, they account themselves great personages here, and each to make his profit without regard of service." 43

The most ambitious of these men, such as Nicholas Malby and Richard Bingham, quickly recognized that they could operate with minimal interference from London, dispense with conventional legal practice, and easily acquire additional land around their garrisons. At the same time, they believed that they were entitled to skim profits from the composition, seize goods, save money by billeting troops without consent, and employ murder, hostage taking, and cattle rustling to intimidate the local population. Rory Rapple, the historian who has written the most detailed study of the actions and attitudes of English soldiers in Ireland, concluded that most did so in full confidence in the morality of their acts in the conviction that their power came explicitly from the crown. ${ }^{44}$

It is true that Elizabeth and her principal advisors, especially William Cecil, sometimes urged caution upon English servitors in Ireland and occasionally disciplined overly zealous English officials, such as Essex and Grey. Elizabeth in particular was sometimes persuaded to temper her policies toward Ireland through her relationship with her cousin, the Irish lord, Thomas Butler, the tenth earl of Ormond. But the reason for their cautionary attitude was not necessarily moral; it was more often fiscal. Elizabethan budgets were always tight, balanced on a razor's edge; provoking a disturbance in Ireland could blow them apart. And, at the times when Ireland became particularly threatening, English officials wanted results; like Hitler, they did not ask many questions about how the results were obtained. ${ }^{45}$

Thus, in two crucial respects, the Nazi Genocide and the Tudor Conquest of Ireland followed similar patterns. There was no plan in either case. Both were improvised tragedies, depending largely on war, international danger, and the interplay of the contingent and unforeseen. Both also depended to a great extent on decisions made by officials in the field. In neither case were there usually explicit orders from above. Those in the field were allowed a great deal of latitude in which to operate and usually did not require or receive specific directions. They did know, however, that the more Jews they killed or the more secure they could make Ireland, the greater rewards they might reap.

One of the most important advances in recent scholarship concerning early modern Ireland involves a more sophisticated understanding of the level of violence perpetrated by English servitors in Ireland. This is of course a critical issue to be addressed concerning the question of whether or not the Nazi Genocide and Tudor Conquest are comparable processes, since it has always appeared that Nazi Genocide was much more lethal and destructive. Similarly, those writing about early modern Ireland, who have been called "reform" historians, have advanced several arguments that also appeared to minimize the destructiveness of the Tudor Conquest. First, they have argued that most English policies in Ireland usually concerned legal and administrative reforms based on negotiation and persuasion rather than violence. Second, they have asserted that Irish lords were the principal purveyors of violence in Ireland and that their violent behavior often forced English servitors to respond in kind. Third, they have contended that if there was extralegal violence in Ireland, it came only late in the century, although they differ upon which point at which it actually began. At the same time, other historians of early modern Ireland have raised questions about whether English violence in Ireland can be considered exceptional, since the English also resorted to violence in other parts of the Tudor state. $^{46}$

David Edwards, however, has raised several objections to these arguments. Conceding that Irish lords were responsible for much of the violence in Ireland, Edwards nevertheless argued that English violence against the Irish was pervasive, begun in the early years of Henry VIII's reign, and continuous throughout most of the Tudor period. It included not only wars,massacres and martial law, but a lengthy and disturbing pattern of widespread violence against the Irish, including women, children, and non-combatants, along with deliberate attempts to destroy crops and cattle with the intent of starving the population. ${ }^{47}$

Much of the violence occurred during the five major wars waged by the English in Ireland during the sixteenth century, including those against Shane O'Neill from 1557 to 1562 and 1563-7, against the Fitzmaurice confederacy from 156973, the earl of Desmond from 1579-83, and the earl of Tyrone from 1594-1603. All told, there was not a year between 1546 and 1603 in which the government of England was not engaged in some sort of military operation in Ireland. ${ }^{48}$ At the same time, the English expanded greatly the size of their military force on the ground and its firepower. An army of about 900 men in 1546 increased to over 2000 men in 1556 and over 4000 in 1566, and, at about this time, archers in the English forces were largely replaced by arguebusiers, who could inflict far more damage on their opponents. ${ }^{49}$ 
As the English military presence increased, the terms of engagement became more violent, and, while massacres that have been entitled as such are the most notorious form of it, there was also large-scale killing of other kinds, sometimes labelled as a massacre, sometimes not. It is not possible in the space of this article to describe every instance of extreme English violence toward the Irish, but many examples can be adduced, in this case, simply those which occurred between 1547 and 1562. In 1547 two-hundred O'More kern were slaughtered by English soldiers. Also in 1547, English forces at the Battle of the Three Castles defeated Irish forces, although most of the killing appears to have been done after the battle. In 1556 Sussex and his Irish ally, the earl of Ormond, massacred two-hundred MacDonnells. A year later, Sussex, after storming Meelick Castle on the banks of the River Shannon, killed all the survivors.

Both Sussex and Henry Sidney were willing in the 1560s to keep killing the MacDonnells even after when they were at peace. In 1562 soldiers under the command of Andrew Brereton surrounded and killed MacDonnell troops as they slept. $^{50}$

The reports of English servitors involved in the Tudor conquest reveal a shocking indifference to the value of Irish life. Lord Grey de Wilton boasted that he had killed 1,485 people, as well as"those of a meaner sort ... the account of which is beside number." ${ }^{51}$ During the same period, Sir William Pelham reported that he and his men "consumed with fire all inhabitation and executed people wherever we found them." In 1586 Sir Richard Bingham, who had served with Grey at Smerwick, surprised about 1,000 Scots gallowglass and their followers, and slaughtered them all. One of Bingham's captains recalled that in his long military experience, he "had never been so weary of killing men...." In the aftermath of his "scorched earth" campaign in Munster, Lord Mountjoy remarked that "we kill so many churls [unarmed peasants] that it grieveth me to think that it is necessary to do this."

The English also routinely executed wandering men and women. Authority for such a practice was a component of the first commissions of martial law issued in 1556 by Sussex, and the practice was continued by subsequent deputies. The English, of course, also imposed harsh treatment on vagabonds in England, but in the case of Ireland they may have been equally harsh, since they were aware that no Irish lord could maintain an army without recruiting vagabonds or without billeting them in the homes of private citizens. Thus, the English waged a consistent campaign not only against vagabonds, but against those who would harbor, aid, or abet rebel activities, which would make them traitors, subject to execution and seizure of their land. Returning from one such expedition, Lord Deputy Sidney admitted that he could not remember how many "varlets" he had killed. ${ }^{53}$ And, just as the Nazis deliberately executed members of the priesthood and the upper class in Poland as well as Soviet commissars, the English in Ireland executed bards, harpers, and rhymers, fearing their subversive potential. ${ }^{54}$

Nazi officials often attempted to deliberately starve persons of groups they wished to eliminate, and there were at least three serious famines caused directly by English campaigns in Ireland, including one in 1557-9 in the east and northeast, in 1580-4 in Munster, and, perhaps, most deadly of all, from 1601-4 in the aftermath of the rebellion of Hugh O'Neill. Of the famine that gripped Munster, the English poet and official in Ireland, Edmund Spenser, who witnessed it, wrote with little evident sympathy, "out of every corner of the woods and glynnes they came creeping forth on their hands, for their legges could not bear them; they looked like anatomies of death; they spake like ghosts crying out of their graves; they did eat the dead carrions, happy where they could find them." 55

The destructiveness of English campaigns also made it difficult for the civilian population to survive. In a portrait repeated all too frequently by other observers, Archbishop George Dowdall reported that the devastation in central and southern Ulster was such that it was possible to ride for miles without seeing signs of life. The signs of famine, however, were everywhere. Houses were burned out and uninhabited; corn fields destroyed and cattle gone. ${ }^{56}$ A quarter century later, Edmund Spenser, described the effects of the English military campaign in Munster in similar terms. "In short space," Spenser observed, "there were none [people or animals] almost left, and a most populous and plentiful country suddenly left void." 57

It is not possible to calculate precisely how many people were killed by English officials, especially since many of those officials, like Sidney and Mountjoy, were unspecific about how many they had killed. But some extrapolation is possible. Based on figures from the Desmond war, one historian has reckoned the loss of Irish life during the Tudor Conquest at roughly 100,000 people. Another has estimated that during the 1580 s alone, the population of Ireland was reduced by $30 \%$. Given that the population of Ireland in 1540 was somewhere between three-quarters of a million and one million people, this represents a surprising death toll, especially when placed in the context of the sixteenth century. It is true that the number of those killed in the Nazi Genocide still far exceeds the number killed in Ireland. But when it is taken into account that the military technology and the number of soldiers available to the Nazis was far superior to that available to the English, it can be argued that these figures can be seen as at least roughly comparable. ${ }^{58}$ 
These are the most important similarities between the Nazi Genocide and the Tudor Conquest of Ireland, but they do not exhaust them. Both the English in Ireland and Nazi officials drew inspiration from classical models of conquest, and in particular the histories of the Roman expansion. As early as the 1530s, Sir Thomas Elyot in his The Book Named the Governor drew attention to the importance of the Roman historian Titus Livy. Livy's principal contention was that the success of Roman expansion, especially in the wars against Carthage, depended primarily upon the appointment of leaders who had the will to seize the moment with the most decisive and, if necessary, ruthless actions. Gabriel Harvey, tutor to Edmund Spenser and a member of an informal group that met regularly to discuss issues of war and colonization, read the works of many classical authors, but rated Livy the most highly.

In the early1570s, members of the group, including Sir Thomas Smith, author of De Republica, Anglorum, published in 1565, and his son, also named Thomas, studied Machiavelli's Discourses on Livy, in preparation for their plan to establish an English colony in Ulster. ${ }^{59}$

Like the English in Ireland, Hitler studied Roman history and drew similar lessons, likening the fall of Carthage to the German surrender in 1918 in the sense that both were the result ofnations that lost the will to fight in the face of adversity and deserved the consequences of their failure. The fall of Carthage, Hitler wrote, "is the most horrible picture of such a slow execution of a people through its own desserts." The conclusion was again clear: victory, whether it was against the Carthaginians, the Irish, or the Jews, would go to the strongest and most resolute. ${ }^{60}$ When some German commanders objected to the savagery of the campaign in Poland, Hitler dismissed their complaints as the childish objections of those who want to wage war with "salvation army methods."

Both groups also evaluated their victims by the standards of an agrarian ideal concerning land utilization. Numerous English observers examined the ways the Irish utilized their lands and found them reprehensible. Their chief complaint was that the Irish were an unsettled, nomadic society, which they believed encouraged the pursuit of a lawless and dissolute life of cattle rustling and banditry. In 1575 Sir Henry Sidney attributed the lack of cultivation in Ireland to the Irish race. At roughly the same time Edward Tremayne blamed the Irish for "the destruction of all husbandrie." Thirty years later, another English observer asserted that when "the breeding of cattle shall cease, then will the rebellion end." Edmund Spenser thought that the Irish should be forced to farm, since the "keeping of cows leads to the idle life," a "fit nursery for a thief." ${ }^{62}$

In the same way, Nazi officials championed the German farmer as the ideal human type. "The farmer," Hitler declared, "is the most important participant in the Nazi Revolution, for a nation cannot exist without farmers." ${ }^{63} \mathrm{He}$ was also aware that agricultural failure brought about the collapse on the home front that led to the German defeat in 1918, and nearly propelled Bolshevism to power in Germany. Thus, he also believed that the entire foreign policy of the Nazi state must be designed to safeguard the existence of those who cultivate the land. In the mind of Heinrich Himmler, Germany's future would be determined by "primeval German peasant warrior and farmer."

Following their military success in Poland and the Soviet Union, the Germans found abundant confirmation for their suspicions about the inferiority of Slavic cultivation. Despite his low expectations for Polish farming, Hitler was still shocked by the pathetic state of Polish agriculture in the Warthegau region and considered pulling back and leaving the region and its wretched people to themselves. ${ }^{65}$ A small group of Germans who had previously farmed in East Africa subsequently took up farming in the Warthegau and immediately set about correcting the myriad of deficiencies they discovered, which included famished topsoil, the necessity of cultivating more than one crop, dilapidated areas for grazing and sheltering pigs and cows, and lack of trees. ${ }^{66}$ Herman Goring thought that Polish farmers utilized barely $10 \%$ of their available land. ${ }^{67}$ The standards implied by the agrarian ideal could also be applied to the Jews, who were essentially an urban population, not "rooted" in the soil, and who were therefore not a real nation. The gypsies, too, were another group not rooted in cultivation; they, too, would have to be destroyed. ${ }^{68}$

In a related concept, both the Tudor Conquest and the Nazi genocide were about land, territorial expansion, and population transfers. Central to Nazi planning was the drive to acquire new lands and the perceived advantages that would accrue from the large-scale transfer of objectionable peoples away from true Germans. At first, the thinking was that they might be transferred somewhere else, like the territory between the Vistula and Bug Rivers in Poland, or to Madagascar. Later, as the Nazis confronted the problem of dealing with Jews and other inferior groups in the conquered areas of Eastern Europe, their answer was to move millions of Jews into ghettoes.By 1942, when the Nazi leadership decided all Jews in conquered areas, including Germany, had to be eliminated, that meant that arrangements had to be made to transport Jews in all the Nazi-occupied areas of Europe to death camps.

English officials involved in the Tudor Conquest also undertook several attempts at population transfer. In the 1550s, Sussex created two new shires along the Pale,called Laois-Offaly, with villages and methods of cultivation modelled along English practice. Sussex believed that the Irish population would come to recognize the superiority of English practice and institutions and be converted to them. ${ }^{69}$ 
In the 1580s, the Munster Plantation was created in the aftermath of the Desmond Rebellion and involved a more ambitious approach. The lands of 136 persons implicated in the rebellion were seized and surveyed. This time the lands would be distributed only to those Englishmen who had assisted in quashing the rebellion or to other persons of English birth, both to provide a model of English society and to ensure the security of Munster in the event of an anticipated Spanish invasion. In particular the English hoped to attract settlers from younger sons of landowning families and especially new settlers from the West Country of England. ${ }^{70}$

There were also several attempts to colonize Ulster. In the 1560s Sir Henry Sidney envisioned a plan to divide the Tyrone lordship among its inhabitants as freeholders to the crown, expel the Scots by military force, and create an area east of the River Bann for civilized English settlement, protected by a network of garrisons.

In the 1570s a major colonizing effort was undertaken in Ulster by Thomas Smith, who argued that its lands were desolate and wasted. Smith proposed developing them through the labor of Irish "churls" under the supervision of the younger sons of English gentlemen, who were without prospects in England. Smith had hoped to recruit at least 500 such men, but in August 1572 he arrived in Ulster with only 100. A third effort to colonize Ulster, led this time by Walter Deveraux, the earl of Essex, ended with the massacre of Sir Brian McPhelim O'Neill and his followers after a Christmas feast, and with Essex's recall to England. ${ }^{71}$

It was never an implemented policy, but in 1596 Edmund Spenser proposed that the English undertake a military conquest of Ireland, commencing with an ultimatum demanding the unconditional surrender of the entire native population. An English army would then lay waste to the land, destroying all goods and livestock, even of those who had submitted to the ultimatum. This campaign of destruction would clear the way to starve the remaining population into submission, and conclude with the dispersion of survivors to different parts of the Ireland in an attempt to destroy all native family and kinship ties. ${ }^{72}$

Both processes were underscored by corruption. Corruption is notoriously difficult to document, but we have already noted the extortionate proclivities of English military captains and Nazi officials. And there are many other examples. In the case of Ireland, Richard Boyle, who has been described as the "exemplar" of the late Elizabethan adventurer in Ireland, amassed an immense personal fortune that would have been difficult to acquire on simply a government salary. ${ }^{73}$ The pervasiveness of corruption points to another similarity. Both the Nazis and the English believed that their endeavors would pay for themselves. In the Nazi case, the profits to be gained by the seizure of Jewish assets and the use of forced Jewish labor were central to their thinking; in the English case, English officials believed, although it was not realized, that the conquest could be financed through martial law and various exactions, such as the cess and a composition rent. $^{74}$

Finally, both sides saw themselves, not as aggressors, but as defenders of an imagined community of religious and racial virtue standing alone against the assault of an evil opposing force. The England of the Elizabethan Age was haunted by fear of an international Catholic conspiracy which would impose the evils of Catholicism upon virtuous English Protestants, thereby jeopardizing their path to salvation. The most likely way for a Catholic conspiracy to unfold would be through a Spanish attack by sea, but English officials also feared greatly the possibility of an invasion of England launched through Ireland. Many English men and women were convinced that, as the Elect Nation, they were experiencing a crisis in which their faith and status as the Elect Nation would face its severest test. ${ }^{75}$

In the same way, the Nazis believed that Germany was threatened by an international Jewish conspiracy to seize its wealth and deny Germany its rightful place in the sun. In the 1930s many Nazileaders believed that a moment of crisis similar to the one faced by Elizabethan Englishmen was at hand. As Hitler stated in his famous 1939 speech to the Reichstag, "if the international Jewish financiers in and outside of Europe should succeed in plunging the nations once more into a world war, then the result will not be the Bolshevizing of the earth, and thus the victory of Jewry, but the annihilation of the Jewish race in Europe., 76

To conclude, it is the contention of this article that the Tudor Conquest of Ireland and the Nazi Genocide can be usefully compared, which is not to claim that they are identical. Ireland in the sixteenth-century was a component of the Tudor state, while European Jews in the twentieth century were stateless. And no one could accuse the sixteenthcentury Irish of being international financiers whose selfish machinations led the world into a Great Depression. The Tudor Conquest did not include gas chambers, ghettoization, a fanatical dictator, or depraved medical experiments, and the frightening devastation of the Nazi Genocide was much greater and occurred over a much shorter period of time, although one could argue that English attempts to control Ireland by force, which occurred between 1520 and 1603 and were almost continuous after 1556, were more sustained and thus comparable. 
But no two historical processes are ever exactly alike, and, even in the case of the Nazi Genocide and the Stalinist terror, which seem comparable on many levels, there are considerable difficulties in sustaining the argument. ${ }^{77}$ But it is clear that the Tudor Conquest and the Nazi Genocide do have a great deal in common, arguably enough to make them worthy of serious comparison. Both were improvised tragedies, unfolding without a real plan, and with goals and strategies that were subject to change as conditions did. Both were driven to a significant extent by ambitious and often corrupt bureaucrats and servitors, influenced by a variable combination of religious prejudice along with classical and agrarian ideals, and who became increasingly eager to partake of the possibilities for wealth and power offered by their positions. Both the English and the Nazis believed that large-scale population transfers could address their problems, and that they occupied the moral high ground. The Nazi Genocide was more ambitious in its scope and more comprehensive in its destruction, but recent work by David Edwards has revealed that the gap between the two, while perceptible, is probably not as wide as was once imagined, and its impact comparable when the limitations of available technology and manpower are taken into account.

${ }^{1}$ Ben Kiernan, Blood and Soil: A World History of Genocide and Extermination from Sparta to Darfur (New Haven: Yale University Press, 2007), p. 437.

${ }^{2}$ Kiernan, Blood and Soil, p. 432.

${ }^{3}$ For works that advocate a generally clear line from Hitler in the 1920s to the Nazi Genocide, see Alan Bullock, Hitler: A Study in Tyranny (New York: Harper and Row, 1952); Andreas Hillgruber, Germany and the Two World Wars (Cambridge, Mass.: Harvard University Press, 1981); the Frank quote can be found in Christopher R. Browning, Nazi Policy, German Killers, Jewish Workers (Cambridge: Cambridge University Press, 2000), p. 8; for a study, though controversial, of the importance of anti-Semitism in the Nazi Genocide, see Daniel Joseph Goldhagen, Hitler's Willing Executioners: Ordinary Germans and the Holocaust (New York: Alfred A. Knopf, 1996).

${ }^{4}$ Richard J. Evans, The Third Reich at War (New York: Penguin, 2008), pp. 285, 318; John Merriman, A History of Modern Europe (New York: Norton, 2010), pp. 1076-80.

${ }^{5}$ Edward Tremayne, "Notes on Ireland, June, 1571," The National Archives, State Papers, 63/32/66.

${ }^{6}$ For two good narratives of sixteenth-century Irish history, see Steven G. Ellis, Ireland in the Age of the Tudors 1447-1603: English Expansion and the End of Gaelic Rule(London: Longman, 1998); Colm Lennon, Sixteenth-Century Ireland: The Incomplete Conquest (Dublin: Gill and MacMillan, 1994); for discussion of violence, see David Edwards, "The Escalation of Violence in Sixteenth-Century Ireland," in David Edwards, Padraig Lenihan, and Clodagh Tait, eds., Age of Atrocity: Violence and Political Conflict in Early Modern Ireland, " pp. 34-78; for details on massacres, see Vincent Carey, "John Derricke's Image of Ireland, Sir Henry Sidney, and the Massacre at Mullagmast," Irish Historical Studies 31(1999): 304-271; idem., "Atrocity and History: Grey, Spenser, and the Slaughter at Smerwick," in Edwards, Lenihan, and Tait," Age of Atrocity, Age of Atrocity, 79-94; idem., "'What Pen Can Paint or Words Atone,' Mountjoy's Scorched Earth Campaign," in Hiram Morgan, ed., The Battle of Kinsale (Bray: Wordwell Press, 2004), pp. 205-16.

${ }^{7}$ For studies of expansion in the early modern English state, see Steve Hindle, The State and Social Change in Early Modern England, 1550-1640; Michael Braddick, State Formation in Early Modern England, 1550-1700 (Cambridge: Cambridge University Press, 2002); specifically for Ireland, Steven G. Ellis, Tudor Frontiers and Noble Power in the Making of the British State (Oxford: the Clarendon Press, 1995); and Hiram Morgan, "Hugh O’Neill and the Nine Years' War in Tudor Ireland,” The Historical Journal 36, 1(March, 1993): 21-37.

${ }^{8}$ For comments along this line, see two articles by Brendan Kane in the special issue of History, including, "Introduction: Human Rights and the History of Violence in the Early British Empire," and“"Ordinary Violence? Ireland as Emergency in the Tudor State," History, 99, (2014): 383-402, and 444-67.

${ }^{9}$ Ian Kershaw, Fateful Choices: Ten Decisions that Changed the World, 1940-1941 (New York: Penquin, 2007), p. 432; Zygmunt Bauman, Modernity and the Holocaust (Ithaca: Cornell University Press, 1989). For a more detailed look at other explanations, see Omer Bartov, Germany's War and the Holocaust: Disputed Histories (Ithaca: Cornell University Press, 2003). For other attempts at comparison, see Alan Bullock, Hitler and Stalin: Parallel Lives (New York: Knopf, 1992; The issue of the uniqueness of the Nazi Genocide was the heart of the "history wars" of the 1980, where historians, such as Ernst Nolte, attempted to "historicize" the Genocide, by arguing that it was not unique. For an interesting commentary on that subject, see Charles S. Maier, The Unmasterable Past: History, Holocaust, and German National Identity (Cambridge, Mass.: Harvard University Press, 1997), esp. pp. 66-99.

${ }^{10}$ One example of change can be seen in recent studies of comparative genocide, where early modern Ireland is now included. See Kiernan, Blood and Soil, pp.169-212; and David Edwards, "Tudor Ireland: Anglicization, Mass Killing, and Security," in Cathie Carmichael and Richard C. Maquire, eds., The Routledge History of Genocide (New York and London: Routledge, 2014), pp. 9-37; see also Benedict Kiernan, “Is 'Genocide' an Anachronistic Concept for the Study of Early Modern Mass Killing?” History 99 (2014): $530-48$.

${ }^{11}$ Kershaw, Fateful Choices,pp. 436-7; and Christopher R. Browning, The Path to Genocide: Essays on Launching the Final Solution (Cambridge: Cambridge University Press, 1992), p. 17.

${ }^{12}$ The works of Ian Kershaw and Christopher Browning have been particularly important in asserting that Nazi racial policies evolved largely as a response to changing military conditions. See especially, Kershaw's biography of Hitler in two volumes. Hitler, 1889-1936 Hubris (New York: Norton, 2000) and Hitler, 1936-1945 Nemesis (New York: Norton, 2004). See also Kershaw, Hitler, the Germans, and the Final Solution (New Haven: Yale University Press, 2008). Kershaw's arguments have been conveniently summarized in his Fateful Choices, pp. 431-70. See Browning, Path to Genocide, p. 27; A similar argument is advanced in Omer Bartov, The Eastern Front, 1941-45: German Troops and the Barbarization of Warfare (New York: St. Martin's, 1986). For more detailed discussions of Nazi practices in Poland, see Alexander Rossino, Hitler Strikes Poland: Blitzkrieg. Ideology, and Atrocity (Lawrence: University Press of Kansas, 2003); and Phillip T. Rutherford, Prelude to the Final Solution: The Nazi Policy for Deporting Ethnic Poles, $1939-1941$ (Lawrence: University Press of Kansas, 2007), esp. 36-87.

${ }^{13}$ Kershaw, Fateful Choices, pp. 445-8; Browning, Path to Genocide, pp. 31-4. 
${ }^{14}$ Kershaw, Fateful Choices, pp. 448-50./

${ }^{15}$ Timothy Snyder, Bloodlands: Europe between Hitler and Stalin (New York: Basic Books, 2010), pp. 169-70.

${ }^{16}$ Kershaw, Fateful Choices, pp. 452-8.

${ }^{17}$ Kiernan, Blood and Soil, p. 452.

${ }^{18}$ Christopher Browning, Ordinary Men: Reserve Police Battalion 101 and the Final Solution in Poland (New York: Harper Collins, 1992), pp. 65-70.

${ }^{19}$ See, Raul Hilberg, The Destruction of the European Jewry (3 vols.; Chicago: Quadrangle Books, 1961); Hannah Arendt, Eichman in Jerusalem: A Report on the Banality of Evil (New York: Viking, 1961); Martin Broszat, The Hitler State: The Foundation and Development of the Internal Structure of the Third Reich (London: Longman, 1981); and Christopher Browning,The Final Solution and the German Foreign Office: A Study of Reverat D III of Abteillung Deutschland, 1940-1943 (New York: Holmes and Maier, 1978).

${ }^{20}$ For a detailed study of Himmler which reveals his willingness to seize any opportunity that would improve his position, see Richard Breitman, The Architect of Genocide: Himmler and the Final Solution (New York: Knopf, 1991); for a broader study of profit motive, see Gotz Aly, Hitler's Beneficiaries: Plunder, Racial War, and the Nazi Welfare State, trans. by Jefferson Chase (New York: Metropolitan Books, 2005).

${ }^{21}$ Richard J. Evans, The Third Reich at War (New York: Penguin, 2009), pp. 41-4, 589.

${ }^{22}$ The phrase of "improvised genocide," comes from Ian Kershaw, "Improvised Genocide? The Emergence of the 'Final Solution' in the Warthegau Region," Transactions of the Royal Historical Society, 2(December, 1992): 51-78;

${ }^{23}$ Steven G. Ellis, "The Kildare Rebellion and the Early Henrician Reformation," Historical Journal 19 (1976): 807-30; Steven G. Ellis, "Tudor Policy and the Kildare Ascendancy in the Lordship of Ireland, 1496-1534," Irish Historical Studies 27 (1977): 235-71; Brendan Bradshaw, The Irish Constitutional Revolution of the Sixteenth Century (Cambridge: Cambridge University Press, 1979); for an overview, see Ciaran Brady, The Chief Governors: The Rise and Fall of Reform Government in Tudor Ireland, 1536-1588 (Cambridge: Cambridge University Press, 1994).

${ }^{24}$ Brady, Chief Governors, pp. 45-71.

${ }^{25}$ Canny, The Elizabethan Conquest, p. 118.

${ }^{26}$ David Edwards, "Beyond Reform: Martial Law and the Tudor Reconquest of Ireland," History/Ireland, 1997), pp. 16-21; Edwards, "Tudor Ireland,"p. 20; Spenser is quoted in Canny, The Elizabethan Conquest, p. 119.

${ }^{27}$ Canny, The Elizabethan Conquest, pp. 47-50.

${ }^{28}$ Canny, The Elizabethan Conquest, pp. 125-36.

${ }^{29}$ Canny, The Elizabethan Conquest, pp. 121-2.

${ }^{30}$ Canny, The Elizabethan Conquest, p. 121.

${ }^{31}$ On this issue generally, see William Palmer, The Problem of Ireland in Tudor Foreign Policy, 1485-1603 (Woodbridge:Boydell Press, 1994); the quote is on p. 54; see also Hiram Morgan, "British Policies before the British State," in Brendan Bradshaw and John Morrill, eds., The British Problem, c. 1534-1707: State Formation in the Atlantic Archipelago (Cambridge, Cambridge University Press, 1996), pp. 66-88, and, Susan Doran, England and Europe, 1485-1603 (London: Routledge, 1991).

${ }^{32}$ Palmer, Problem of Ireland, pp. 141-2.

${ }^{33}$ Cyril Falls, Elizabeth's Irish Wars (New York: Barnes and Noble, 1950), p. 9.

${ }^{34}$ Lambeth Palace Library, Carew Mss., 614/272; Calendar of Carew Mss., Preserved at Lambeth, 1515-1574, 6 vols., (London, 1860- ): $1: 300-2$

${ }^{35}$ Sir Henry Nicholas, Memoirs of the Life and Times of Sir Christopher Hatton (London, 1847), p. 158.

${ }^{36}$ The National Archives, State Papers,Elizabeth, Foreign, 70/39/106-7.

${ }^{37}$ Calendar of State Papers, Foreign, Elizabeth, 23 vols., ed. Joseph Stevenson et al, (London: Public Record Office, (1863-1950), 5:370 (852).

${ }^{38}$ Jennifer Loach, Parliament under the Tudors (Oxford: Oxford University Press, 1991), pp. 108-9.

${ }^{39}$ Malcolm Thorpe, "Catholic Conspiracy in Early Elizabethan Foreign Policy," Sixteenth Century Journal 15, 4(Winter, 1984): 431-49.

${ }^{40}$ Palmer, Problem of Ireland, pp. 109-15; for a study of the deeper study of the issues involved in the rebellion, see Ciaran Brady, "Faction and the Origins of the Desmond Rebellion," Irish Historical Studies, 22, 80(1981): 289-312.

${ }^{41}$ In addition to the works cited in n. 35; see Christopher Maginn, "The Baltinglass Rebellion, 1580: English Dissent or Gaelic Uprising?" The Historical Journal47, 2(June, 2004): 205-232.

${ }^{42}$ Canny, The Elizabethan Conquest, pp. 70, 82, and 88-9; Ciaran Brady, "Conservative Subversives: the Community of the Pale and the Dublin Administration, 1556-86," in P. J. Corish, ed., Radicals, Rebels, and Establishments: Historical Studies, 30, (1996): 11-32.

${ }^{43}$ Rory Rapple, Martial Power and Elizabethan Political Culture, 1558-1594 (Cambridge: Cambridge University Press, 2009 ), p. 165.

${ }^{44}$ Rapple, Martial Power, pp. 169-170.

${ }^{45}$ See the essays in Brendan Kane and Valerie McGowan-Doyle, eds., Elizabeth I and Ireland (Cambridge: Cambridge University Press, 2014); for Cecil, see Christopher Maginn, William Cecil, Ireland, and the Tudor State (Oxford: Oxford University Press, 2012).

${ }^{46}$ For the arguments of "reform" historians, see especially the works of Ellis and Brady; and Brendan Kane's essays in the special issue of History cited in notes 6,7.It should also be noted that perpetrators often use the violent behavior of the victims to justify their acts. See the interesting article by Rafael Scheck, “'They Are Just Savages:' German Massacres of Black Soldiers from the French Army in 1940," Journal of Modern History 77, 2(June, 2005): 325-44. According to Scheck, the Germans massacred French colonial troops during World War I and World War II, and, in both cases blamed their actions on the behavior of the victims.

${ }^{47}$ Edwards' ideas can be found in several places, including his article on martial law (see n.21), his contribution to the Age of Atrocity volume (see n.5), and his contribution to the Routledge History of Genocide, (see n.9).

${ }^{48}$ Edwards, "Tudor Ireland," p. 23.

${ }^{49}$ Edwards, "The Escalation of Violence," p. 66.

${ }^{50}$ Edwards, "The Escalation of Violence, pp.72-3. 
${ }^{51}$ Edwards, "Tudor Ireland," p. 33

${ }^{52}$ Kiernan, Blood and Soil, pp. 206-7.

${ }^{53}$ Edwards, "The Escalation of Violence," p. 74.

${ }^{54}$ Edwards, "Tudor Ireland," p. 32.

${ }^{55}$ Edwards, "Tudor Ireland," pp. 33-4; Edmund Spenser, A View of the Present State of Ireland, Andrew Hadfield and Wily Maly, eds., (Oxford, Oxford University Press, 1997), pp. 101-2.

${ }^{56}$ Edwards, "Tudor Ireland," p. 23.

${ }^{57}$ Spenser is quoted in Edwards, “Tudor Ireland," p. 23

${ }^{58}$ Hiram Morgan, “'Never Any Realm Worse Governed,' Queen Elizabeth and Ireland," Transactions of the Royal Historical Society 14(2004), p. 308; cited in Edwards, "Tudor Ireland," p. 23; for other population figures, see Kiernan, Blood and Soil, p. 203, and S.J. Connolly, Contested Island: Ireland, 1460-1630 (Oxford: Oxford University Press, 2007), pp. 404-5; Raymond Gillespie, The Transformation of the Irish Economy. 1550-1700 (Dundalk, 1991), pp. 12-14.

${ }^{59}$ Kiernan, Blood and Soil, pp. 171-2; see also Hiram Morgan, “The Colonial Venture of Sir Thomas Smith," Historical Journal 29, 2(1985): 261-278.

${ }^{60}$ Kiernan, Blood and Soil, pp. 420-22.

${ }^{61}$ Kershaw, Hitler, (London and New York: Longman's), 1991), p. 151

${ }^{62}$ Kiernan, Blood and Soil, pp. 179, 181, 185. But, see John Patrick Montano, The Roots of English Colonialism in Ireland (Cambridge University Press, 2010). Montano demonstrated that while English observers insisted that Ireland was a nomadic, unsettled society, they ignored considerable evidence to the contrary.

${ }^{63}$ Kiernan, Blood and Soil, p. 423.

${ }^{64}$ Kiernan, Blood and Soil, p. 427.

${ }^{65}$ Rutherford, Prelude to the Final Solution, p. 68.

${ }^{66}$ Kiernan, Blood and Soil, p. 452.

${ }^{67}$ Rutherford, Prelude to the Final Solution, p. 72.

${ }^{68}$ Kiernan, Blood and Soil, p. 430.

${ }^{69}$ A good summary of English plantation activity can be found in Lennon, Sixteenth Century Ireland, pp.208-36, for Munster; and pp. 27492 for Ulster.

${ }^{70}$ Michael McCarthy-Morrogh, The Munster Plantation: English Migration to Southern Ireland 1583-1641(Oxford: Clarendon Press, 1986), p. 27; Lennon, Sixteenth-Century Ireland, pp. 229-34.

${ }^{71}$ Canny, The Elizabethan Conquest, pp. 120-1; Lennon, Sixteenth Century Ireland, p. 279.

${ }^{72}$ Spenser, View of the Present State of Ireland; Andrew Hadfield, Spenser and Ireland: Wylde Fruit and Salvage Soil (Oxford: Oxford University Press,, 1997); see also Ciaran Brady, "Spenser's Irish Crisis: Humanism and Experience in the 1590s," Past and Present, 111(1986), pp. 30-1.

${ }^{73}$ Nicholas Canny, The Upstart Earl: A Study of the Social and Mental World of Richard Boyle: The First Earl of Cork, $1566-1643$ (Cambridge: Cambridge University Press, 1982); for the quote, see R.F. Foster, Modern Ireland 1600-1972 (New York: Penguin, 1989), p. 14.

${ }^{74}$ Brady, "Conservative Subversives," pp. 16-21; Ciaran Brady, "Court, Castle, and Country: The Framework of Government in Tudor Ireland," p. 49, in Ciaran Brady and Raymond Gillespie, eds., The Making of Irish Colonial Society: Essays in the Making of Irish Colonial Society, 1534-1641 (Dublin: Irish Academic Press, 1986).

${ }^{75}$ There is a large literature on this question, but see especially, William Haller, The Elect Nation: The Meaning and Relevance of Foxe's Book of Martyrs (New York, 1973), and Carol Z. Wiener, "The Beleaguered Isle: A Study of Elizabethan and Early Jacobean AntiCatholicism,"Past and Present51 (May, 1971): 27-62, especially pp. 29-30.

${ }^{76}$ Kershaw, Fateful Choices, pp. 433-4.

${ }^{77}$ Maier, The Unmasterable Past, pp. 69-99. 